Cultures de bêtes... Outils qui pensent ?

\title{
Humains ou malins : bêtes et robots
}

Jean-Luc Jamard

\section{OpenEdition}

Journals

Édition électronique

URL : https://journals.openedition.org/tc/579

DOI : $10.4000 /$ tc. 579

ISSN : 1952-420X

\section{Éditeur}

Éditions de l'EHESS

\section{Édition imprimée}

Date de publication : 1 novembre 1995

ISSN : 0248-6016

\section{Référence électronique}

Jean-Luc Jamard, « Humains ou malins : bêtes et robots », Techniques \& Culture [En ligne], 23-24 |

1995, mis en ligne le 09 décembre 2005, consulté le 29 septembre 2022. URL : http://

journals.openedition.org/tc/579; DOI : https://doi.org/10.4000/tc.579

Ce document a été généré automatiquement le 29 septembre 2022

Tous droits réservés 


\section{Humains ou malins : bêtes et robots}

Jean-Luc Jamard 